\title{
PULMONARY AND BIOCHEMICAL CHARACTERISTICS OF SMOKER AND NON-SMOKER MODERN DANCERS
}

\author{
CARACTERISTICAS PULMONARES E BIOQUÍMICAS DE DANÇARINOS MODERNOS \\ FUMANTES ENÃO-FUMANTES
}

Original Articie

Artigo Original

Artículo Original

\author{
CARACTERÍSTICAS PULMOMARES Y BIOQUIMMICAS DE BAILARINAS MODERNAS \\ FUMADORAS Y NO FUMADORAS
}

Ani Agopyan 1

(Sport and Exercise Scientist)

Mehmet Unal ${ }^{2}$

(Medical Doctor)

Demet Tekin ${ }^{3}$

(Sport and Dance Physiotherapist)

Hizir Kurtel ${ }^{4}$ (Medical Doctor)

Gullu Turan ${ }^{5}$ (Phyical Educator)

Ayrin $\mathrm{ErsOz}^{6}$ (Dance Scholar)

1. Marmara University, School of Physical Education and Sports,

Department of Trainer Education, Istanbul, Turkey.

2. Yeni Yuzyil University, Faculty of Health Sciences,Department of Physiotherapy and Rehabilitation, Istanbul, Turkey.

3. Istanbul Bilgi University, School of Health Sciences, Department of Physiotherapy and Rehabilitation, Istanbul, Turkey.

4. Marmara University, School of Medicine, Department of Sports Physiology, Istanbul, Turkey. 5. Department of Health, Culture and Sports, Uskudar University, Istanbul, Turkey.

6. Yildiz Technical University, Dance Program Faculty of Arts and Design, Department of Music and Performing Arts, Istanbul, Turkey.

\section{Correspondência:}

Marmara Universitesi, Beden Eğitimi ve Spor Yüksekokulu, Anadoluhisarı Yerleşkesi, Cuma yolu cad., 34800. Beykoz, Istanbul, Turkey. aniagopyan@marmara.edu.tr

\begin{abstract}
Introduction: Although the harmful effects of smoking on the cardiovascular and respiratory systems have been established for a long time, the effect on physiological and physical parameters in modern female dancers is not well documented. Objective: To determine differences in selected pulmonary functions, biochemical parameters, and body composition in female smoker and non-smoker modern dancers who are university or graduate students. Methods: A total of twenty-two female modern dancers (mean age of $24.6 \pm 4.3$ years), who were non-smokers $(n=11)$ and smokers $(n=11)$, voluntarily participated in the study. The smokers had been smoking 1 to 20 cigarettes per day for an average period of seven years. The pulmonary function test Mir Spirobank Spirometer, (Italy) was applied; selected biochemical parameters were tested, and various anthropometric measurements (height, weight and seven skinfold thickness) were performed. The results of body composition were evaluated using Jackson-Pollock equations. Intergroup comparisons were performed using the Mann-Whitney U test. Result: No significant differences were found between smoker and non-smoker dancers in terms of body composition (body fat, $\%$ body fat, lean body fat) and selected biochemical parameters ( $p>0.05)$. However, non-smokers had prediction values of forced expiratory volume during the first second (FEV1) and peak expiratory flow (PEF) significantly better $(p<0.05)$. The effect of smoking on the performance of female modern dancers should be examined in a longitudinal study, with a higher number of participants. Conclusion: It was observed that smoking reduces lung pulmonary capacity at a certain rate, although the biochemical parameters and body composition of the female smoker and non-smoker dancers were similar.
\end{abstract}

Keywords: tobacco, respiratory function tests, blood chemical analysis, adipose tissue, dancing.

\section{RESUMO}

Introdução: Embora os efeitos nocivos do fumo nos sistemas cardiovascular erespiratório tenham sido estabelecidos há muito, o efeito sobre os parâmetros fisiológicos efísicos em bailarinas de dança moderna não foi bem documentado ainda. Objetivo: Determinar as diferenças em funções pulmonares selecionadas, parâmetros bioquímicos e composição corporal em bailarinas de dança moderna fumadoras e não-fumadoras, universitárias e pós-universitárias. Métodos: Vinte e duas bailarinas de dança moderna (média de idade de 24,6 $\pm 4,3$ anos), não fumantes $(n=11)$ e fumantes $(n=11)$, participaram voluntariamente no estudo. As fumantesconsumiram de 1 a 20 cigarros por dia durante uma média de sete anos. Foi aplicado o teste funcional pulmonar Mir Spirobank Spirometer, (Itália), alguns parâmetros biomédicos selecionados foram testados e foram realizadas várias medições antropométricas (altura, peso e sete espessuras de pregas cutâneas). Os resultados da composição corporal foram avaliados usando equações Jackson-Pollock. As comparações intergrupo foram realizadas usando o teste "U" de Mann-Whitney. Resultado: Não foram encontradas diferenças significativas entre as bailarinas fumantes e não fumantes quanto à composição corporal (gordura corporal, $\%$ massa gorda, massa corporal magra) e nos parâmetros bioquímicos selecionados ( $p>0,05)$. No entanto, as não fumantes tinham valores de predição do volume expiratório forçado no primeiro segundo (VEF1) e pico de fluxo expiratório (PFE) significativamente melhores $(p<0,05)$. O efeito do tabagismo no desempenho de bailarinas de dança moderna deveria ser examinado num estudo longitudinal, com um maior número de participantes. Conclusão: Foi observado que o fumo reduz a capacidade pulmonar a uma certa taxa, embora os padrões bioquímicos e a composição corporal das bailarinas fumantes e não fumantes fossem semelhantes.

Descritores: tabaco, testes de função respiratória, análise química do sangue, tecido adiposo, dança.

\section{RESUMEN}

Introducción: Aunque los efectos nocivos del tabaco en los sistemas cardiovasculary respiratorio hayan sido establecidos hace mucho, el efecto sobre los parámetros fisiológicos y físicos en bailarinas de danza moderna no fue aún bien documentado. Objetivo: Determinar las diferencias en funciones pulmonares seleccionadas, parámetros bioquímicos y composición corporal en bailarinas de danza moderna fumadoras y no fumadoras, universitarias y post universitarias. Método: Veintidós bailarinas de danza moderna (edad promedio de 24,6 $6 \pm 4,3$ años), no fumadoras ( $n=11$ ) y fumadoras ( $n=11$ ), participaron voluntariamente en el estudio. Las fumadoras habían fumado desde 1 hasta 20 cigarrillos por día 
durante un promedio de siete años. Fue aplicado el test funcional pulmonar espirómetro Mir Spirobank, (Italia), y fueron hechos algunos tests de parámetros biomédicos seleccionados y hechas varias mediciones antropométricas (altura, peso y siete espesores de los pliegues cutáneos). Los resultados de la composición corporal fueron evaluados usando ecuaciones Jackson-Pollock. Las comparaciones intergrupales fueron realizadas usando el test Mann-Whitney U. Resultado: No fueron encontradas diferencias significativas entre bailarinas fumadoras y no fumadoras en la composición corporal (grasa corporal, \% de masa grasa, masa corporal magra) y en los parámetros bioquímicos seleccionados ( $p$ $>0,05$ ). Sin embargo, las no fumadoras tuvieron valores de predicción del volumen espiratorio forzado en el primer segundo (VEF1) y del flujo espiratorio máximo (FEM) significativamente mejores $(p<0,05)$. El efecto del tabaco en el desempeño de bailarinas de danza moderna debería ser examinado en un estudio longitudinal, con un aumento del número de participantes. Conclusión: Se observó que el tabaco reduce la capacidad pulmonar a una cierta tasa, aunque los estándares bioquímicos y la composición corporal de las bailarinas fumadoras y no fumadoras fueron similares.

Descriptores: tabaco, pruebas de función respiratoria, análisis químico de la sangre, tejido adiposo, baile.

\section{INTRODUCTION}

Modern dance is a type of art that generally involves some of complex movements of the body. Since the body is the instrument of the dancer's expression, it has been suggested ${ }^{1}$ that physiological and motoric capabilities as well as body composition are equally important components of physical fitness.

Good health is required to be successful in dance life, and health risks have to be taken into consederation for dance training and performance to achieve best results. Because dancers are among the hardest training athletes, health promotion within dancers and good health behaviours would benefit the individual. Cigarette smoking is one of the 10 leading risk factor for death². It is a significant public health issue in the world and also in Turkey ${ }^{3}$. As a major cardiovascular risk factor smoking has a potential to increase the likelihood of exercise-induced cardiac events ${ }^{4}$. Some studies reported that smoking has been found to have a negative impact on musculoskeletal health ${ }^{5}$ but others found no significant association ${ }^{6}$. Smoking is believed to be detrimental to athletic performance because it leads to premature fatigue or muscular failure which may in turn affect athletic performance ${ }^{7}$. There is also evidence to suggest that participation in sport may serve as a protective factor against smoking-induced harm in health ${ }^{8}$. The prevalence of smoking in elite athletes is actually many times lower than in the general population ${ }^{9}$. Depending on the dose, cigarette smoking has been shown to increase serum hemoglobin and hematocrit levels, increase lung volume and stimulate weight loss characteristics all known to enhance performance in endurance sports ${ }^{9}$.

On the other hand, there have been very few studies focused on cigarette smoking and alcohol consumption in dance population and were mostly done in ballet dancers ${ }^{10-12}$ folk dancers $^{10}$ and sport dancers ${ }^{12}$ while studies of modern dancers ${ }^{11}$ are even more limited. Previous research has reported that ballet dancers have the highest percentage of smokers (43\%), followed by modern dancers $(32 \%)^{11}$. Smoking has adverse effects on dancers, including increased injury rate, increased comorbid behaviors, and other health issues ${ }^{12}$.

Although the deleterious effects of smoking on cardiovascular, respiratory and musculoskeletal systems have long been established ${ }^{2-5,7}$, the effect on physiological, biochemical and physical parameters in smoker and non-smoker modern dancers has not been well documented. Identifying the different factors that may adversely affect the performance of the dancers is vital for protecting the health of dancers. Therefore, the aim of this study was to determine differences in selected pulmonary functions, hematological parameters, and body composition in smoking and non-smoking university and graduate modern dancers.

\section{MATERIAL AND METHODS}

The study used a design to determine the differences of physiological, biochemical and physical parameters between smoker and non-smoker modern dancers. A total of 22 female modern dancers were voluntarily participated in this study. Dancers were university and graduated modern dance students aged 19 to 31 years old (mean age: $24.6 \pm 4.3$ years). The study group was composed of individuals practicing modern dance for at least five years. Participants, according to their smoking habits, were divided into two groups: Smokers $(n=11)$ and non-smokers $(n=11)$. A smoker was defined by the presence of regular smoking of any type of cigarettes for one year or more. Demographic data, including smoking and medical histories were obtained from the participants by questionnaire. Information on number of cigarettes and the duration of smoking was also obtained. None of the participants included in the study have been diagnosed with acute or chronic diseases. An exclusion criterion was a history of cardiovascular or diseases representing contraindications to exercise. The dancers received information and clarification about the procedures for the evaluations, as well as the risks and benefits. After having received the clarifications, the individuals signed a Free and Clarified Consent Form. This research was approved by the Research Ethical Committee of Marmara University, Faculty of Medicine, Istanbul, Turkey, under the number (SAG-D-040712-0272).

All participants visited the research unit twice and they were familiarized with all experimental tests before baseline performance. The tests were completed in two days and in a same condition.The dancers were requested not to perform strenuous exercise 24 hours before testing. They were instructed to avoid drinking or eating at least 8-hour before blood samples were taken. On the first testing session, blood samples were taken. On the second testing session, the anthropometric and the pulmonary function measurements were done in the morning about 2 hours after a breakfast.

Haematological and biochemical analyses were conducted within 2 hours after taking the blood in the Biochemistry Laboratory, which has accreditation of the World Health Organization (WHO)-certified laboratories. Blood plasma and serum samples were analyzed according to the standard laboratory operating procedures. All blood samples of dancers were collected from the antecubital vein in the morning (8:30- 9:30 AM), after 8-hour fast and at least 12 hours without training or any other form of exercise. Prior to the procedures, the dancers remained at full rest during $30 \mathrm{~min}$. None of the female dancers were in menstruation cycle. Blood samples were collected in a seated position into vacutainer tubes (Vacuette, Greiner BioOne, SP, Brazil) containing the anticoagulant EDTA-K3. Three $\mathrm{mL}$ of blood was drawn in an EDTA containing evacuated test tube (B-D Biosciences, Dallas, USA) for 
hematologic analysis and five $\mathrm{mL}$ of blood was drawn in a plain evacuated test tube for biochemical analysis.

Venous blood samples were drawn to determine haematological blood variables, including number of erythrocytes (RBC- $\left.\mathrm{M} / \mathrm{mm}^{3}\right)$, hemoglobin concentration $(\mathrm{Hb}-\mathrm{g} / \mathrm{dl})$, hematocrit value (Hct- \%), number of leukocytes (WBC- K/ mm³), lymphocytes (LYMP-\%) and monocytes (MON-\%). Biochmical analyses were done for serum sodium ( $\mathrm{mmol} / \mathrm{L}$ ), serum potassium ( $\mathrm{mmol} / \mathrm{L})$, serum Chloride ( $\mathrm{mmol} / \mathrm{L})$, serum total calcium $(\mathrm{mg} / \mathrm{dl})$, serum total magnesium $(\mathrm{mg} / \mathrm{dl})$ and plasma glucose $(\mathrm{mg} / \mathrm{dl})$. The hematological parameters were analyzed in automated equipment (Pentra 120; ABX Diagnostics, Montpellier). The reference values used were those indicated by the adopted methods.

The anthropometric test measures were conducted by specialists (AA) who had a degree in kinanthropometry with certification. Measurements were done while the participants were wearing light clothing and no shoes. Body height was measured using a portable anthropometer (Holtain, Crymich, UK) to the nearest $0.5 \mathrm{~cm}$. Body mass was obtained to the nearest $0.1 \mathrm{~kg}$ using a balance beam scale (Seca, Hamburg, Germany). The scales were calibrated before data collection. Body mass index (BMI) was calculated with the formula: $\mathrm{BMI}=\left[\text { Body weight }(\mathrm{kg}) / \text { height }^{2}\left(\mathrm{~m}^{2}\right)\right]^{13}$.

Body composition analysis were evaluted by using skinfold thicknesses technique to determine the individual levels of body mass (BM), fat mass (FM), and lean tissue mass (LM). Skinfold thicknesses were measured at the right side of the body to the nearest $0.2 \mathrm{~mm}$ by means of a Holtain skinfold caliper (Holtain Ltd., Crosswell, UK) at seven sites: triceps, subscapular, suprailiac, chest, abdomen, thigh and midaxillary. All measurements were carried out in duplicate and the mean recorded value was used. Body densities were determined using the sum of seven skinfolds (SF-7) in Jackson \& Pollock equation and body fat percentage estimates generated from the Siri formula ${ }^{13}$. The body composition was determined by the following formulas ${ }^{13}$ :

Body Density (BD) $=1.097-0.00046971 \times($ sum of SKF) +0.00000056 $\mathrm{x}(\text { sum of SKF) })^{2}-0.00012828 \times$ (age).

Body fat Percentage $(\% B F)=[(4.95 / B D)-4.5] \times 100$.

Fat Mass $(F M)=(B F \% / 100) \times$ Weight.

Fat Free Mass (FFM) $=$ Weight - Fat mass

Lung function tests were performed with a computerized spirometer (MIR, Spirobank, Italy) according to the American Thoracic Society guidelines ${ }^{14}$ by a physican (MU). The test was performed in each dancer in the sitting position using a nose clip. During the procedure, the participant inhaled deeply and then exhaled with maximum effort in to the mouth piece. The following variables were obtained from the best of three reproducible forced expiratory maneuvers: Forced vital capacity (FVC), percent of forced vital capacity (FVC \%), forced expiratory volume in one second $\left(\mathrm{FEV}_{1}\right)$, percent of predicted $\mathrm{FEV}_{1}\left(\mathrm{FEV}_{1} \%\right), \mathrm{FEV}_{1} / \mathrm{FVC}$ ratio, peak expiratory flow (PEF), two parameters of forced expiratory flow (FEF): FEF 50 and FEF 25-75 tidal volume (TV), inspiratory capacity (IC) and maximal voluntary ventilation (MV). For all maneuvers, attempts were repeated, with a 30s interval between each attempt to prevent the development of respiratory muscle fatigue, until a maximum value was reached. All variables were then converted into percentage predicted values and each spirometric value was calculated according to the dancer's age, sex, weight and height. FEV1 is the volume of air that is forcibly exhaled in the first second. FVC is the total volume of air exhaled after a full inspiration. Mean forced expiratory flow (FEF) is value during the middle half (25\%-75\%) of the FVC. It is more sensitive than FEV1 to small changes in the airway resistance. It is less effort dependent and more reproducible.

\section{Statistical analyses}

Descriptive statistics methods were applied, in which data are presented in mean, standard deviation, minimum and maximal values. Normality of variables was confirmed by

the Kolmogorov-Smirnov test data was expressed as means \pm SD. The Mann-Whitney $U$ test was used to identify significant differences between the two groups. The statistical significance was considered at probability value of $P<0.05$.

\section{RESULTS}

Anthropometric and training characteristics of the dancers are presented in Table 1. There were no significant differences between groups, with regard to age, weight, height, BMl or dance experience $(p>0.05)$. But weekly dance experience was significantly higher in smoker dancers than the non-smoker dancers $(p<0.001)$.The mean values of BMls (Table 1), pulmonary function parameters (Table 2), selected hematological and biochemical parameters (Table 3) were within the normal ranges for the smoker and non-smoker dancers. No significant differences ( $p>0.05$ ) were found between the smoker and non-smoker dancers in body fat, \% body fat and lean body fat, selected hematological and biochemical parameters (Table 2). While the non-smokers had significantly $(p<0.05)$ better first-second-\% predict (FEV1\% predict) and peak expiratory flow (PEF best) values (Table 3), there were no significant differences between groups in the reminder parameters of pulmonary tests ( $p>0.05$ ). The smokers had been smoking 1-20 cigarettes (mean $=7.9 \pm 5.9$ number/day) per day for $7.4( \pm 4.6)$ years.

Table 1. General characteristics and dance experience of non-smokers and smokers dancers.

\begin{tabular}{c|c|c|c}
\hline \multirow{2}{*}{ Parameters } & $\begin{array}{c}\text { Non-smokers } \\
\text { dancers } \\
(\mathbf{n = 1 1 )}\end{array}$ & $\begin{array}{c}\text { Smokers } \\
\text { dancers } \\
(\mathbf{n}=\mathbf{1 1})\end{array}$ & \multirow{2}{*}{ P value } \\
\cline { 2 - 3 } & Mean \pm SD & Mean \pm SD & \\
\hline Age (years) & $23.2 \pm 3.6$ & $26.1 \pm 4.7$ & 0.133 \\
\hline Height (cm) & $161.4 \pm 5.4$ & $163.1 \pm 6.1$ & 0.562 \\
\hline Weight (kg) & $51.7 \pm 5.9$ & $53.1 \pm 5.2$ & 0.438 \\
\hline BMl (kg/m $\left.{ }^{2}\right)$ & $19.8 \pm 1.6$ & $20.0 \pm 1.9$ & 0.847 \\
\hline Total dance training per week (hours) & $15.5 \pm 1.8$ & $24.9 \pm 10.1$ & $0.007^{*}$ \\
\hline
\end{tabular}

$\mathrm{BMI}=$ body mass index; $\mathrm{SD}=$ standard deviation; Mann-Whitney $\mathrm{U}$ test with $\mathrm{p}<0.01$.

Table 2. Statistical analyses values of body composition and pulmonary test parameters between non-smokers and smokers dancers.

\begin{tabular}{|c|c|c|c|}
\hline Parameters & $\begin{array}{c}\text { Non-smoker dancers } \\
(n=11)\end{array}$ & $\begin{array}{c}\text { Smoker dancers } \\
(n=11)\end{array}$ & \multirow[t]{2}{*}{ P value } \\
\hline Body composition & Mean \pm SD & Mean \pm SD & \\
\hline Body Fat (\%) & $17.3 \pm 3.5$ & $16.8 \pm 4.4$ & 0.567 \\
\hline Body Fat (kg) & $9.1 \pm 2.9$ & $9.0 \pm 2.8$ & 0.797 \\
\hline Lean Body Fat (kg) & $42.6 \pm 3.7$ & $44.1 \pm 4.0$ & 0.332 \\
\hline \multicolumn{4}{|l|}{ Pulmonary tests } \\
\hline FVC $(\mathrm{L})$ & $3.5 \pm 0.5$ & $3.7 \pm 0.4$ & 0.438 \\
\hline FVC \% & $102.9 \pm 12.1$ & $98.4 \pm 14.3$ & $0.005^{* *}$ \\
\hline $\mathrm{FEV}_{1}(\mathrm{~L})$ & $3.2 \pm 0.4$ & $3.2 \pm 0.3$ & 0.797 \\
\hline $\mathrm{FEV}_{1} \%$ & $102.6 \pm 13.1$ & $101.4 \pm 12$ & 0.748 \\
\hline $\mathrm{FEV}_{1} / \mathrm{FVC}(\mathrm{L})$ & $99.3 \pm 13.2$ & $92.5 \pm 17.1$ & 0.133 \\
\hline PEF (L/min) & $104.1 \pm 4.7$ & $98.3 \pm 5.7$ & $0.010^{*}$ \\
\hline FEF \%25-75 (L/s) & $91.8 \pm 14.6$ & $83.8 \pm 17.1$ & 0.332 \\
\hline FEF \%50 (L/s) & $80.1 \pm 19.5$ & $83.8 \pm 18.0$ & 0.652 \\
\hline TV $(\mathrm{ml} / \mathrm{kg})$ & $6.2 \pm 0.2$ & $7.0 \pm 0.2$ & 0.512 \\
\hline IC $(\mathrm{L})$ & $2.9 \pm 0.5$ & $3.1 \pm 0.4$ & 0.512 \\
\hline MVV (L/min) & $118.6 \pm 20.5$ & $114.0 \pm 19.6$ & 0.748 \\
\hline
\end{tabular}

$\mathrm{FVC}=$ Forced vital capacity; $\mathrm{FVC} \%$ = percent of forced vital capacity; $\mathrm{FEV}_{1}=$ forced expiratory volume in on second; $F E V, \%=$ percent of forced expiratory volume in one second; $\mathrm{PEF}=$ peak expiratory flow; $\mathrm{PEF}=$ percent of predicted; $F E F=$ forced expiratory flow; TV = tidal volume; $I C=$ inspiratory capacity; $M V V=$ maximal voluntary ventilation; SD = standard deviation; Mann-Whitney U test with ${ }^{*} p \leq 0.05 ;{ }^{* *} p \leq 0.01$. 
Table 3. Statistical analyses values of hematologic test parameters between non-smoker and smoker dancers.

\begin{tabular}{c|c|c|c|c}
\hline \multirow{2}{*}{ Parameters } & $\begin{array}{c}\text { Confidence } \\
\text { interval 95\% }\end{array}$ & $\begin{array}{c}\text { Non-smoker } \\
\text { dancers } \\
\mathbf{( n = 1 1 )}\end{array}$ & $\begin{array}{c}\text { Smoker } \\
\text { dancers } \\
\mathbf{( n = 1 1 )}\end{array}$ & \multirow{2}{*}{ P value } \\
\cline { 3 - 4 } & Mean \pm SD & Mean \pm SD & \\
\hline Glucose $(\mathrm{mg} / \mathrm{dl})$ & $60-110$ & $96.6 \pm 9.2$ & $97.6 \pm 8.8$ & 0.898 \\
\hline Sodium $(\mathrm{mmol} / \mathrm{L})$ & $136-145$ & $139.0 \pm 1.5$ & $138.9 \pm 1.8$ & 0.606 \\
\hline Potassium $(\mathrm{mmol} / \mathrm{L})$ & $3.5-5.1$ & $4.7 \pm 0.4$ & $4.9 \pm 0.4$ & 0.133 \\
\hline Chloride $(\mathrm{mmol} / \mathrm{L})$ & $98-107$ & $103.1 \pm 1.7$ & $104 \pm 1.0$ & 0.076 \\
\hline Calcium $(\mathrm{mg} / \mathrm{dl})$ & $8.8-10.2$ & $9.9 \pm 0.5$ & $9.7 \pm 0.3$ & 0.065 \\
\hline Magnesium $(\mathrm{mg} / \mathrm{dl})$ & $1.7-2.55$ & $2.2 \pm 0.1$ & $2.1 \pm 0.1$ & 0.898 \\
\hline Serum iron, umol/L & $19.1-21.2$ & $20.6 \pm 2.1$ & $20.1 \pm 3.1$ & 0.789 \\
\hline Hemoglobin $(\mathrm{g} / \mathrm{dl})$ & $11-16.5$ & $12.8 \pm 1.6$ & $12.6 \pm 0.9$ & 0.270 \\
\hline Hematocrit \% 3 & $35-50$ & $37.8 \pm 4.1$ & $37.6 \pm 2.3$ & 0.606 \\
\hline Erythrocyte $(\mathrm{M} / \mathrm{mm})$ & $3.8-5.8$ & $4.4 \pm 0.3$ & $4.6 \pm 0.4$ & 0.365 \\
\hline Leucocyte $(\mathrm{K} / \mathrm{mm})$ & $3.5-10$ & $6.2 \pm 0.9$ & $5.6 \pm 0.9$ & 0.193 \\
\hline Lymphocyte \% & $17-48$ & $34.1 \pm 6.8$ & $38.5 \pm 5.5$ & 0.116 \\
\hline Monocyte \% & $4-10$ & $8.1 \pm 2.4$ & $7.5 \pm 0.9$ & 0.898 \\
\hline SD = standard deviation; Mann-Whitney U test with p: significance level $(\mathrm{p}>0.05)$. &
\end{tabular}

\section{DISCUSSION}

This study analyzed, for the first time, the differences of biochemical and hematological parameters, pulmonary functions, and body composition between smoker and non-smoker modern dancers in graduated and university level students. The main finding of this study was that there were not significant differences between the smoker and non-smoker modern dancers in body composition (body fat, \% body fat, lean body fat) and selected biochemical and hematological parameters. However, the non-smokers had significantly better first-second-\% predict (FEV1 \% predict) and peak expiratory flow (PEF best) values.

Pulmonary function is governed by genetic, environmental and nutritional factors and also, workloads or the intensity of training programme increase the lung volume and the capacity. Swimmers and weight lifters who have most strenuous respiratory muscle exercise have better pulmonary function tests (PFTs) compared to the sprinters who have mostly depend on anaerobic capacity. There is evidence that regular training significantly increases FVC, FEV1and MVV in athletes than nonathletes ${ }^{15}$ but there is not enought information in the literature regarding pulmonary function of the modern dancers.

Modern dance is a vigorous physical activity requiring high level of cardiovascular demand to accomplish work loads during rehearsals and performances in the stage. The dancers need high aerobic and anaerobic energy capacity during their performance depending to their choreography'. However, because dance training does not elicit enough stimuli to increase aerobic fitness ${ }^{16}$, it is much more important to keep the structure of the cardiovascular and cardiorespiratory system of the dancers strong and healthy. In addition to it's many other harmful effects on human body, smoking effects the cardiovascular and cardiorespiratory health as well ${ }^{4}$. It has been suggested that the intensity or severity of physical activity engaged in by the athletes the extent of strengthening of respiratory muscles with resultant increase in lung volume and capacities ${ }^{15}$. In the present study, although the smoking group had more weekly training hours, the results of respiratory function tests FEV1\% and PEF of the smoking group dancers were lower than the nonsmoking group dancers. These results can be attributed to the negative effects of smoking on the respiratory function tests of the dancers.

The FEV $1 \%$ predict and PEF best parameters are important for pulmonary funcion. FEV is the volume of air that is forcibly exhaled in the first second and it is the most significant parameter for identifying both the restrictive and obstructive respiratory diseases. The value of $\mathrm{FEV}_{1}$ is very essential in quantifying airflow limitation. It is also a powerful predictor of increased risk of lung cancer and cardiovascular diseases ${ }^{17}$. PEF is at least as important for prognosis as FEV $\mathrm{F}_{1}$. PEF requires an aerobic-type activity where there is a need to forcefully and rapidly expel air in an attempt to exchange gases as rapidly as possible ${ }^{18}$. It is concluded that ventilation, i.e. the convective gas transport in the respiratory system, is better in non-smoker dancers than smoker dancers. Smoker dancers have developed great disorders of ventilation obstructive type. Decrease in ventilatory function may become a more important limiting factor of aerobic capacity with increased age ${ }^{19}$. Furthermore, pulmonary function decline and obstructive lung disease are also known to be strongly associated with tobacco smoke exposure, and dose-response relationship has been implicated by Pletcher et al. ${ }^{20}$. In present study, the smokers had been smoking 1-20 cigarettes (mean=7.9 \pm 5.9 number) per day for $7.4( \pm 4.6)$ years. As the years progress, exposure to smoking and it's negative effects increase, therefore it is very important for the smoker dancers of present study to take this fact into consederation and take measures accordingly to protect their health. The respiratory capacity of the smoker dancers should be tested at regular intervals.

Physical training itself has no significant effect on selected hematological variables in athletes compared with untrained controls. The specific type and duration of exercise is of major importance in the adaptations of the blood cell system and the iron metabolism especially in the female athlete population ${ }^{21}$. The changes, due to dancing, in the blood and biochemical parameters of modern dancers and the effects of smoking on these parameters are not well documented in the literature.

The result of the present study show that, smoker and nonsmoker dancers were within normal range of hematological and biochemical values. Generally dancers of groups were not anemic. Hemoglobin and hematocrit are important red cells which reflect the red blood cell count. Hemoglobin and hematocrit values of our study are lower than Fallon's2 ${ }^{22}$ hemoglobin $(13.4 \pm 0.8 \mathrm{~g} / \mathrm{dL})$ and hematocrit $(0.39 \pm 0.02)$ results which he obtained from elite women athletes. This could be attributed to the fact that the predominant energy system required for participation in sport effects hematological parameters ${ }^{23}$.

In the present study, smokers compared to non-smokers had smilar mean hemoglobin and hematocrit values, which are not in agreement with previous report ${ }^{24}$ that generally focused on sedantary people. It is determined that in normal population the hemoglobin values of smokers are higher than non smokers ${ }^{24}$. Carbon monoxide is a major component of cigarette smoke and it reduces oxygen tension in the body. The elevation of hemoglobin and hematocrit by smoking is explained by elevation of carbon monoxide. To compensate for this decreased oxygen delivery, smokers maintain a higher hemoglobin level than nonsmokers ${ }^{24}$. Cigarette smokers who smoke 40 or more cigarette per day have $\mathrm{Hb}$ levels that are, on average $0.7 \mathrm{~g} / \mathrm{l}$ higher compared with nonsmokers ${ }^{24}$. In our study the number of cigarettes smoked per day is lower (mean 7.9 \pm 5.9 number/day) which could be the reason for not seeing the effect of above mentioned mechanism.

Electrolits such as $\mathrm{Na}, \mathrm{K}$ and $\mathrm{Cl}$, minerals such as $\mathrm{Ca}$ and $\mathrm{Mg}$ play the main role of maintaining osmotic pressure and water distrubition in various fliud compartments of the body. They have also other roles such as, orginazing the function of cardiac and skeletal muscle and Ph, electron transfer reactions, being enzym co-factors. The values which are used to determine the water and electrolite balance were within normal range and similar for smoker and nonsmoker dancers.

The body compositions of the dancers serve as the means for achieving both the physiological needs of a healthy body and the esthetic goal of thinness to obtain maximum on-stage performance ${ }^{25}$. For the dancer's health it is important to keep the body composition in certain values. Preliminary research has shown comparable lean body mass in dancers to that of untrained controls ${ }^{26}$. Depending on the 
study, it has been reported that ballet dancers mean levels of fatness ranged from 13.8 to $22.1 \%{ }^{25}$. Martyn-Stevens et al. ${ }^{27}$ found that USA female collegiate modern dancers had a percent body fat of $\sim 18 \%$. The present study indicated that the smoker (16.8\%) and non smoker (17.3\%) dancers had very similar percent body fat.These results are similar to the results of Martyn-Stevens et al. ${ }^{27}$ which used the same body composition equation as well. Our results indicate that the Turkish female modern dancers studied constitute a group of lean women with a mean body fat of $\sim 17 \%$. This value takes within the range of $17-23 \%$ body fat which was proposed by Chmelar and Fitt $^{28}$ as an optimum body composition for university adult female dancers. An individual's body fat must be high enough to sustain proper functioning of the nervous system, maintenance of cell membrane integrity, and normal hormonal function ${ }^{26}$. With this perspective, the present study illustrates that university modern dancers are within a healthy body composition.

Smoking a single cigarette has been shown to induce a $3 \%$ rise in energy expenditure within $30 \mathrm{~min}$. Nicotine acutely increases energy expenditure and could reduce appetite, which likely explains why smokers tend to have lower body weight than do nonsmokers. Also, there is increasing evidence that smoking affects body fat distribution and that it is associated with central obesity and insulin resistance ${ }^{29}$. In the previous study generally examined the relation between smoking and body composition in obese population ${ }^{29}$. But there is not yet enough evidence for the effects of smoking to the body composition of the dancers. In the present study, smokers and non-smokers were similar body composition (body fat, \% body fat, lean body fat). This result can be interpreted as smoking not having a significant effect on body composition. On the other hand, Chiolero et al. ${ }^{29}$ indicated that heavy smokers (ie, those smoking a greater number of cigarettes/d) have greater body weight than do light smokers. The result of present study which showed that smoking does not have a significant effect on body composition of the dancers can be explained with the fact that the participants were light smokers.
One of the limitations of this study was having limited number of participants and the other was, information about the smoking level of the participants was based on participants' own testimony. Despite these limitations, the preset study is among the first to highlight the deleterious effects on respiratory functions caused by smoking in modern dancers. Further studies are needed to better understand the mechanism related to the respiratory function and smoking in female and also male modern dancers. The effect of smoking on the performance of the modern dancers should be examined in a longitudinal study, with an increase in the number of participants.

\section{CONCLUSION}

Based on our results, we can conclude that smoking causes significant changes in some respiratory function, as is evidenced by the highlighted changes in the components of the FEV1\% predict and PEF best, although biochemical parameters and body composition of smoker and non-smoker dancers were similar. We recommend testing pulmonary capacity periodically, especially for the smoker dancers for the reasons that have adverse effects on pulmonary function. Promoting smoking cessation should therfore be a major priority in all dance educaters and for all health professionals.

\section{ACKNOWLEDGMENTS}

Marmara University, Scientific Research Project Committee that supported financial assistance for this protect (project no. SAG-D-040712-0272). We also thank Yildiz Technical University, Faculty of Arts and Design, the Department of Music and Performing Arts, Dance Program and their modern dance students who participated in this study.

All authors have declared there is not any potential conflict of interests concerning this article.

CONTRIBUIÇÕES DOS AUTORES: Each author contributed individually and significantly to the development of the manuscript. AA (0000-0001-6407-4648)* and DT $(0000-0002-7508-104 X)^{*}$ were the main contributors in the drafting of the manuscript. MU (0000-0002-9275-3020** and GT (0000-0002-9306-8965)* gathered clinical data with AA (0000-0001-6407-4648)* and DT (0000-0002-7508-104X)*. AA (0000-0001-6407-4648)* evaluated data statistical analysis. AA (0000-0001-6407-4648)*, DT $(0000-0002-7508-104 X)^{*}$ and GT (0000-0002-9306-8965)* performed the literature research. HK (0000-0003-3633-7863)* Mehmet Unal and A E (0000-0002-9501-2981)* also performed the literature search and revised of the manuscript and edited the study. *ORCID Number (Open Researcher and Contributor ID).

\section{REFERENCES}

1. Angioi M, Metsios GS, Koutedakis $Y$, Wyon MA. Fitness in contemporary dance: a systematic review. Int J Sports Med. 2009;30(7):475-84

2. Mathers C, Stevens G, Mascarenhas M. Global Health Risks: Mortality and burden of disease attributable to selected major risks. Geneva, Switzerland: WHO; 2009.

3. Bilir, N, Çakır B, Dagli E, Erguder T, Onder Z. Tobacco control in Turkey. Copenhagen: WHO Europe; 2009.

4. van Teeffelen WM, de Beus MF, Mosterd A, Bots ML, Mosterd WL, Pool J, et al. Risk factors for exercise-related acute cardiac events. A case-control study. Br J Sports Med. 2009;43(9):722-5.

5. Barendregt JJ, Bonneux L, van der Maas PJ. The health care costs of smoking. N Engl J Med. 1997;337(15):1052-7.

6. Cox JM, Trier KK. Exercise and smoking habits in patients with and without low back and leg pain. J Manipulative Physiol Ther. 1987;10(5):239-45.

7. Adedoyin RA, Mbada CE, Odiachi AM, Adegoke BO, Awotidebe TO. Differences in back extensor muscles fatigability for smoking and non-smoking athletes. Isokinet Exerc Sci. 2010;18:149-55.

8. Lisha NE, Sussman S. Relationship of high school and college sports participation with alcohol, tobacco, and illicit drug use: a review. Addict Behav. 2010;35(5):399-407.

9. Myers KA. Holiday reading: Cigarette smoking: an underused tool in high-performance endurance training. CMAJ. 2010;182(18):E867-9.

10. Oreb G, Ruzić L, Matković B, Misigoj-Duraković M, Vlasić J, Ciliga D. Physical fitness, menstrual cycle disorders and smoking habit in Croatian National Ballet and National Folk Dance Ensembles. Coll Antropol. 2006:30(2):279-83.

11. Stensland SH, Sobal J. Dietary practices of ballet, jazz, and modern dancers. J Am Diet Assoc. 1992;92(3):319-24.

12. Zenic N, Peric M, Zubcevic NG, Ostojic Z, Ostojic L. Comparative analysis of substance use in ballet, dance sport, and synchronized swimming: results of a longitudinal study. Med Probl Perform Art. 2010;25(2):75-81.

13. Balady GJ, Berra KA, Golding LA, Gordon, NF, Mahler, DA, Myers JN et al. ACSM's Guidelines for exercise testing and prescription. 6th ed. Philadelphia: Lippincott; 2000.

14. American Thoracic Society. Single-breath carbon monoxide diffusing capacity (transfer factor). Recommendations for a standard technique--1995 update. Am J Respir Crit Care Med. 1995;152(6 Pt 1):2185-98.

15. Mahotra NB, Shrestha L. Effects of type sports on pulmonary function tests: A comparative study in
Nepalese settings. J Nobel Med Coll. 2013;2(1):18-21

16. Wyon MA, Redding E. Physiological monitoring of cardiorespiratory adaptations during rehearsal and performance of contemporary dance. J Strength Cond Res. 2005;19(3):611-4.

17. Kavitha A, Sujatha CM, Ramakrishnan S. Prediction of spirometric forced expiratory volume (FEV1) data using support vector regression. Measurement Sci Review 2010;10(2):63-7.

18. Shaw I, Shaw BS, Brown GA. Concurrent training and pulmonary function in smokers. Int J Sports Med. 2011;32(10):776-80

19. Degens H, Maden-Wilkinson TM, Ireland A, Korhonen MT, Suominen H, Heinonen A, et al. Relationship between ventilatory function and age in master athletes and a sedentary reference population. Age (Dordr). 2013;35(3):1007-15

20. Pletcher MJ, Hulley BJ, Houston T, Kiefe Cl, Benowitz N, Sidney S. Menthol cigarettes, Smoking cessation, atherosclerosis, and pulmonary function: the Coronary Artery Risk Development in Young Adults (CARDIA) Study. Arch Intern Med. 2006;166(17):1915-22.

21. Schumacher YO, Schmid A, Grathwohl D, Bültermann D, Berg A. Hematological indices and iron status in athletes of various sports and performances. Med Sci Sports Exerc. 2002;34(5):869-75.

22. Fallon KE. Utility of hematological and iron-related screening in elite athletes. Clin J Sport Med. 2004;14(3):145-52.

23. Milic R, Martinovic J, Dopsaj M, Dopsaj V. Haematological and iron-related parameters in male and female athletes according to different metabolic energy demands. Eur J Appl Physiol. 2011;111(3):449-58.

24. Leifert JA. Anaemia and cigarette smoking. Int J Lab Hematol. 2008;30(3):177-84.

25. Yannakoulia M, Keramopoulos A, Tsakalakos N, Matalas AL. Body composition in dancers: the bioelec trical impedance method. Med Sci Sports Exerc. 2000;32(1):228-34.

26. Wilmerding V, Gibson A, Mermier C, Bivins KA. Body composition analysis in dancers. J Dance Med Sci. 2003;7:24-31

27. Martyn-Stevens BE, Brown LE, Beam WC, Wiersma LD. Effects of a dance season on the physiological profile of collegiate female modern dancers. Med Sport. 2012;16(1):1-5.

28. Chmelar RD, Fitt S. Diet: A complete guide to nutrition and weight control (dancing at your peak) East Windsor, NJ: Princeton Book Company; 1990

29. Chiolero A, Faeh D, Paccaud F, Cornuz J. Consequences of smoking for body weight, body fat distribution, and insulin resistance. Am J Clin Nutr. 2008:87(4):801-9. 